\title{
Global Invasion Risk Assessment of Prosopis juliflora at Biome Level: Does Soil Matter?
}

\author{
Mohammed A. Dakhil ${ }^{1}\left(\mathbb{D}\right.$, Ali El-Keblawy ${ }^{2, * \mathbb{D}}$, Mohamed A. El-Sheikh ${ }^{3} \mathbb{D}$, Marwa Waseem A. Halmy ${ }^{4}$, \\ Taoufik Ksiksi ${ }^{5}$ D and Walaa A. Hassan ${ }^{6}$
}

1 Botany and Microbiology Department, Faculty of Science, Helwan University, Cairo 11790, Egypt; mohamed_dakhil@science.helwan.edu.eg

2 Department of Applied Biology, Faculty of Science, University of Sharjah, Sharjah P.O. Box 27272, United Arab Emirates

3 Botany \& Microbiology Department, College of Science, King Saud University, P.O. Box 2455, Riyadh 11451, Saudi Arabia; melsheikh@ksu.edu.sa

4 Department of Environmental Sciences, Faculty of Science, Alexandria University, Alexandria 21511, Egypt; maraw.w.halmy@alexu.edu.eg

5 Biology Department, United Arab Emirates University, Al Ain 15258, United Arab Emirates; tksiksi@uaeu.ac.ae

6 Botany and Microbiology Department, Faculty of Science, Beni-Suef University, Beni-Suef 62511, Egypt; azmeyw@gmail.com

* Correspondence: akeblawy@sharjah.ac.ae

check for updates

Citation: Dakhil, M.A.; El-Keblawy, A.; El-Sheikh, M.A.; Halmy, M.W.A.; Ksiksi, T.; Hassan, W.A. Global Invasion Risk Assessment of Prosopis juliflora at Biome Level: Does Soil Matter? Biology 2021, 10, 203. https://doi.org/10.3390/ biology10030203

Academic Editor: Maria Amélia Martins-Loução

Received: 19 January 2021 Accepted: 25 February 2021 Published: 9 March 2021

Publisher's Note: MDPI stays neutral with regard to jurisdictional claims in published maps and institutional affiliations.

Copyright: (c) 2021 by the authors. Licensee MDPI, Basel, Switzerland. This article is an open access article distributed under the terms and conditions of the Creative Commons Attribution (CC BY) license (https:// creativecommons.org/licenses/by/ $4.0 /)$.
Simple Summary: Invasive plant species are one of the major threats to biodiversity and cause the loss of natural habitats. Invasive Mesquite plant was continuing to spread all over the world and invaded most of the forest-shrubland biomes. We aimed to evaluate the contribution of soil and huaman-influence factors and climatic factors to the distribution dynamics and expansion of Mesquite invasive plant. Also, it aimed at ranking the threatened areas in each global biome. Our findings revealed that the invasion risk increases with temperature, soil alkalinity, and clay fractions. This study would provide great insights into prioritization and management guidelines to monitor the expansion and invasion risk of Mesquite plant in the whole world.

Abstract: Prosopis juliflora is one of the most problematic invasive trees in tropical and subtropical regions. Understanding driving forces affecting the potential global distribution would help in managing its current and future spread. The role of climate on the global spatial distribution of P. juliflora has been well studied, but little is known about the role of soil and human impacts as potential drivers. Here, we used maximum entropy (MaxEnt) for species distribution modelling to understand the role of climate $(\mathrm{C})$, soil $(\mathrm{S})$ and human impacts $(\mathrm{H}), \mathrm{C}+\mathrm{S}$, and $\mathrm{C}+\mathrm{S}+\mathrm{H}$ in controlling the potential invasion range of $P$. juliflora, and to project its global potential invasive risk. We defined the top threatened global biomes, as predicted by the best-selected model. The incorporation of the edaphic factors improved the model performance and enhanced the accuracy of the outcome. Our findings revealed that the potential invasion risk increases with increases in mean temperature of the driest quarter (Bio9), soil alkalinity and clay fractions. Arid and semi-arid lands are at the highest risk of invasion than other moist biomes.

Keywords: invasion risk assessment; temperature variability; habitat suitability; global biomes; MaxEnt; conservation priority

\section{Introduction}

The increase in human travel and trade has accidentally or intentionally increased the spread of many species from their native ranges [1]. The increasing numbers of introduced invasive species and their potential to change the social-ecological systems have been considered a major global change component [2-4]. The ecological impacts of the introduction 
of invasive plants include, for example, degradation of ecosystem structure and function, change in community composition, and loss of species diversity $[5,6]$. Invasive exotic plants have become among the major challenges facing social-ecological systems, especially rangelands and livestock [4]. The social-ecological impacts of introduced invasive plants would be severe without applying effective and preventive management approaches [7].

Prosopis L. (Fabaceae) has 44 species of trees and large shrubs [8]. Prosopis juliflora is the hardiest and most resilient xerophytic tree of the genus, originated from North America (Mexico) or Central America (Costa Rica, El Salvador, Guatemala, Honduras, Nicaragua, Panama). It is naturalized and invaded several tropical and sub-tropical regions worldwide at an alarming rate [1,9]. In addition, this species is surviving and thriving in the harsh conditions of the hyperarid Arabian deserts, where annual average rainfall is less than $100 \mathrm{~mm}$ and average temperatures reach above $40^{\circ} \mathrm{C}$ during summer [10-15]. The introduction was for different purposes, including for example, combating desertification and land reclamation, greening deserts, and its utilization as sources of animal feed, especially pods that represent a considerable part of goats' diet, biofuel, timber, shelter, building material and furniture for local farmers $[1,8,16]$. However, after its introduction, $P$. juliflora turned to be one of the most problematic trees globally, particularly in the rangelands, croplands, and forests, and threatens the pastoral livelihoods and ecosystems. The IUCN has considered $P$. juliflora as one of the worst 100 invasive alien species globally $[17,18]$.

Several environmental factors helped the rapid invasion of $P$. juliflora to new ranges. For example, the hardy nature of $P$. juliflora and its ability to tolerate a wide range of temperature, water/soil quality, and humidity makes it among successful invasive species to the hot, dry, and wet tropical and subtropical regions. Moreover, plants' ability to adopt a wide range of climatic and soil conditions, high coppicing ability, effective dispersal mechanisms and production of allelochemicals accelerated the invasion rate of P. juliflora $[19,20]$. Furthermore, this species propagates both sexually with vast numbers of viable seeds and vegetatively by adventitious buds present on the shallow roots. The dormant seeds build long-lasting seed banks as a bet-hedging strategy against unfavorable years of below-average precipitation or drought [21]. Such diversity in the propagation methods enabled $P$. juliflora to successfully colonize new areas [22,23].

Among several algorithms, maximum entropy (MaxEnt) was regarded as one of the best bioclimatic species distribution models (SDMs). MaxEnt uses presence-only data to predict species distribution [24]. Several studies have used SDMs and MaxEnt to predict the invasion of introduced plants at a continental scale, based on their occurrence records and preferable environmental variables. Most studies have used climatic, environmental variables to model invasive plant distribution [25]. However, there are numerous environmental variables that can affect the ability of models to predict the distribution of invasive plants [26]. For example, the use of other environmental factors, such as soil, water and human impacts, in addition to the climatic data, should provide higher predictive powers in SDMs [27].

Several researchers have used the SDM to study the impacts of climate change on future invasion and distribution range of $P$. juliflora at local and regional scales $[7,28,29]$. For example, Wakie et al. [28] concluded that Moderate Resolution Imaging Spectroradiometer (MODIS) vegetation indices and species occurrence points with MaxEnt modeling software could be used to quantify the current distribution of P. juliflora. Moreover, [29] studied the effect of global warming on the distribution of P. juliflora in its introduced range using SDMs and MaxEnt approach. They concluded that more than $87 \%$ of the model's variations were explained in the light of the annual mean temperature, annual precipitation, and temperature means diurnal range. Besides, it has been reported the intolerance to low temperatures was the most critical factor that limits the global distribution of P. juliflora; the level, duration, and frequency of frosts limit the reproduction and growth of this species [9].

Several studies have reported the importance of using combinations of predictor variables to understand the complex interplay between biological invasions and global environmental distribution to understand plant invasion [30]. For example, several models 
indicated that soil factors could affect the physiological performance of invasive plants and, therefore, could affect their distribution range [31,32]. Despite the fact that several studies have studied the effect of climatic factors on the potential distribution of P. juliflora, few have assessed the roles of soil attributes as well human pressures as potential environmental drivers that could affect the distribution of this species. For example, Nascimento et al. [33] have recently shown that both soil properties and human activities could be potential drivers for the distribution, proliferation, and invasion ability of $P$. juliflora. They concluded that some life-history traits of this species could help it to benefit from human activities. For example, grazing animals could increase seed dispersal, germination, and enhance soil fertility, enhancing the dispersal of P. juliflora to new habitats, even in less-fertile degraded lands. In addition, [28] reported that the inclusion of soil and related hydrologic parameters in the spatial distribution models could provide more insights into the current and potential distribution of P. juliflora.

Furthermore, Abbas et al. [34] modeled the spatial distribution of P. juliflora along an environmental gradient in Upper Egypt. They concluded that elevation and distance from the road, as an indicator of human disturbance, significantly correlated with its ability to spread in new habitats. However, little knowledge is known about human impacts and soil variability on the potential distribution of P. juliflora at a global scale [32]. We expect that incorporating soil properties and human impact data into SDMs would provide more accurate and precise predictions of the potential distribution, hence the invasion risk of $P$. juliflora. Therefore, the objectives of the current study were to estimate the global potential invasion risk of $P$. juliflora using three different models: climate (C), climate and soil $(\mathrm{C}+\mathrm{S})$, and climate, soil, and human influence $(\mathrm{C}+\mathrm{S}+\mathrm{H})$. The study also aimed at ranking the top threatened global biomes based on the potential invasion suitability produced by the best-selected model.

The combination of more predictor variables would help explain the complex interplay between biological invasions and the global environment and the socio-economic processes and provide more insights towards effective management of the invasive P. juliflora. Moreover, incorporating soil quantity data into SDMs would provide more accurate and precise predictions of the invasion risk (i.e., the potential distribution of $P$. juliflora under current conditions of climate and soil. To the best of our knowledge, this is the first study involving potential evapotranspiration and aridity index, wind speed, solar radiation variables along with soil variables simultaneously into the SDM to investigate the global pattern of distribution of $P$. juliflora. These variables can potentially affect the growth and potential distribution of plant species, and this incorporation could improve the prediction of plant distribution [35]. The overall result would help determine the best predictor variable(s) that could explain the potential distribution of P. juliflora.

\section{Materials and Methods}

\subsection{Global Distribution Data}

We obtained the occurrence data of P. juliflora from the Global Biodiversity Information Facility (GBIF.org, https:/ / doi.org/10.15468/dl.sgpgg0 (accessed on 13 December 2018)). The downloaded database hosts 1752 geo-referenced records (1950-2018), including coordinates. The source of these occurrence data was human observations and preserved specimens. We verified the records using ArcGIS 10.3 [36] to remove records outside the shapefile [36] of the world map or located in water and deleted duplicate geographical records. This resulted in 1173 distribution points representing 35 world countries (Figure 1 and Supplementary A, Table S1), which were reduced further into 866 records representing 34 countries after deleting the reciprocated missing values of the resampled environmental variables of climate, topography, and soil. 


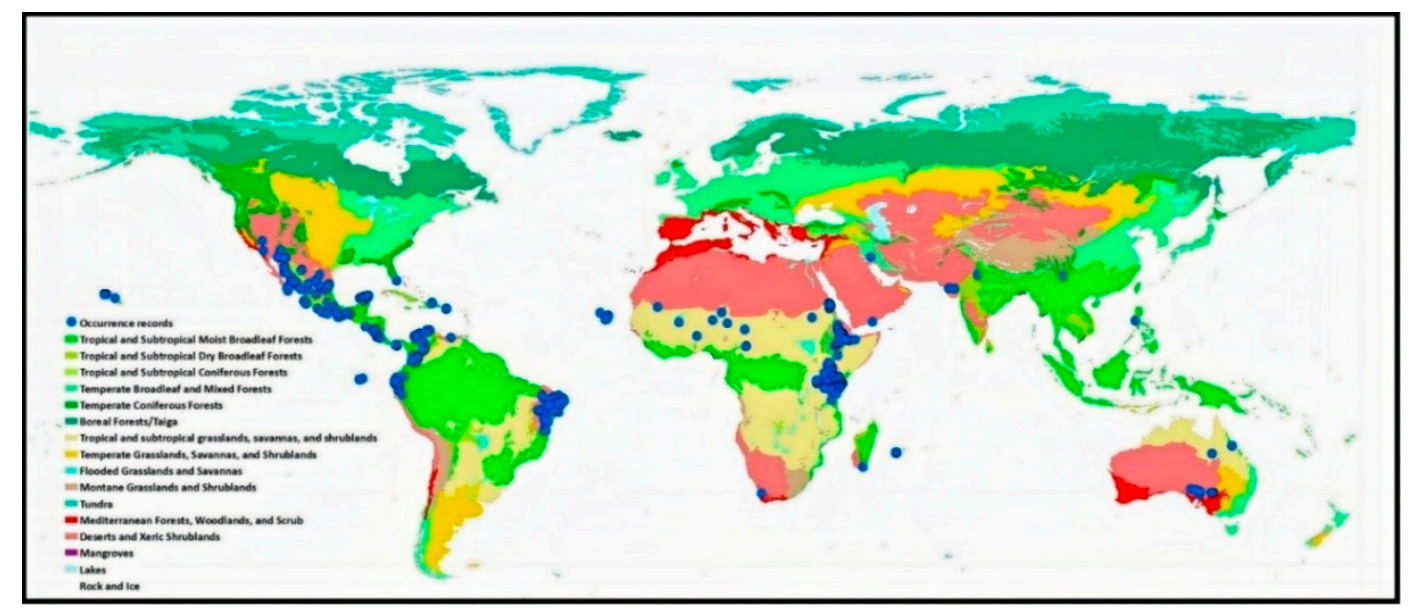

Figure 1. Global distribution of the sixteen terrestrial biomes and the occurrence records of $P$. juliflora.

\subsection{Environmental and Human Variable Predictors}

\subsubsection{Bioclimatic Variables}

To predict the potentially suitable habitats for P. juliflora in the world, we downloaded the nineteen standards bioclimatic variables of the current climate (1970-2000) from the WorldClim 2.0 along with wind speed and solar radiation (http:/ / www.worldclim.org; accessed on 7 April 2019 [37]) at a spatial resolution of 2.5 arc-minutes $(\sim 5 \mathrm{~km} \times 5 \mathrm{~km}$ at the equator). We generated the mean raster layers of the monthly layers of wind speed and solar radiation using the spatial analyst toolbox in ArcGIS 10.3 [36].

The data of potential evapotranspiration (PET), actual evapotranspiration (AET) and aridity index (AI) were downloaded from CGIAR-CSI Global database ([38]; www.cgiarcsi.org; accessed on 16 May 2017) at a spatial resolution of 30 arcseconds ( 1 km at the equator), and then resampled into resolution 2.5 arc-minutes using ArcGIS10.3 [36].

\subsubsection{Edaphic Variables}

Nine quantitative variables representing the soil physical and chemical properties were downloaded from the ISRIC-World Soil Information database (ftp: / ftp.soilgrids.org/ data / aggregated; accessed on 27 March 2019 [39] at a depth of 0-2 $\mathrm{m}$ and a spatial resolution of 30 arcseconds. The mean raster layers of the different soil depths were generated using the spatial analyst toolbox and then resampled into a resolution of 2.5 arc-minutes using ArcGIS10.3 [36].

\subsubsection{Human-Activity Variable}

The Global Human Influence Index Dataset of the Last of the Wild Project is a global dataset of $1-\mathrm{km}^{2}$ grid cells [39] was created from nine global data layers covering human population pressure, human land use, and infrastructure (land use/land cover, built-up areas and nighttime lights), and human access (roads, railroads, coastlines, and navigable rivers). The human influence data was resampled into a resolution of 2.5 arc-minutes using ArcGIS10.3 [36].

\subsection{Multicollinearity, Model Construction, and Predictions}

All the environmental data (34 variables; see Supplementary A, Table S2) were extracted from the raster layers using species occurrence records in ArcGIS 10.3 [36] for multicollinearity analysis of the environmental predictors to avoid overfitting of models, poor model performance, and misleading interpretations. The climatic and edaphic predictors were analyzed separately, and only the predictors with correlation coefficient "Spearman" or "Pearson" $|\mathrm{r}| \leq 0.7$ (Supplementary A, Table S3 and Table S4) and ecophysiologically meaningful were selected for the model development [40]. We used IBM SPSS v.21.0 [40] to perform multicollinearity analysis. 
We converted 15, out of the 34 environmental predictors (Table 1), in addition to human influence index predictor layers, into ASCII format before their use for MaxEnt models. We used the resolution of 2.5 arc-minutes to allow more flexibility of the interactive geographical relationship between the species and its environment; this resolution was used previously in similar studies concerned with global distribution modelling of invasive plant species such as Phragmites australis [41] and Parthenium hysterophorus [42].

Table 1. List of the predictor variables used in the distribution modelling of P. juliflora. All data were standardized to 2.5 arc-min spatial resolution.

\begin{tabular}{|c|c|c|c|c|}
\hline Variable & Code & Description & Original Resolution & Source \\
\hline \multirow{9}{*}{ (1) Climate } & Bio_4 & $\begin{array}{c}\text { Temperature seasonality [Coefficient } \\
\text { of Variation }(\mathrm{C} \text { of } \mathrm{V}) \text { ] }\end{array}$ & 2.5 arc-min & www.worldclim.org \\
\hline & PET & potential evapotranspiration (mm) & 30 arc-sec & CGIAR-CSI Global database \\
\hline & Solar_rad & solar radiation $\left(\mathrm{kJ} \mathrm{m}^{-2}\right.$ day $\left.^{-1}\right)$ & 2.5 arc-min & www.worldclim.org \\
\hline & & aridity index & 30 arc-sec & CGIAR-CSI Global database \\
\hline & Wind_spd & wind speed $\left(\mathrm{m} \mathrm{s}^{-1}\right)$ & 2.5 arc-min & www.worldclim.org \\
\hline & Bio_8 & $\begin{array}{l}\text { mean temperatures of the wettest } \\
\text { quarter }{ }^{*}\left({ }^{\circ} \mathrm{C}\right)\end{array}$ & 2.5 arc-min & www.worldclim.org \\
\hline & Bio_9 & $\begin{array}{c}\text { Mean temperature of the driest } \\
\text { quarter }\left({ }^{\circ} \mathrm{C}\right)\end{array}$ & 2.5 arc-min & www.worldclim.org \\
\hline & Bio_15 & precipitation seasonality $(\mathrm{C}$ of $\mathrm{V})$ & 2.5 arc-min & www.worldclim.org \\
\hline & Bio_16 & precipitation of wettest quarter $(\mathrm{mm})$ & 2.5 arc-min & www.worldclim.org \\
\hline \multirow{6}{*}{ (2) Soil } & PHIHOX & \multirow{6}{*}{$\begin{array}{c}\text { soil } \mathrm{pH} \times 10 \text { in } \mathrm{H} 2 \mathrm{O} \\
\text { cation exchange capacity in cmolc } / \mathrm{kg} \\
\text { soil texture fraction clay in percent } \\
\text { soil organic carbon content in } \mathrm{g} \text { per } \mathrm{kg} \\
\text { coarse fragments volumetric in } \\
\text { percent } \\
\text { Available soil water capacity }\end{array}$} & 30 arc-sec & ISRIC-World Soil Database \\
\hline & CEC & & 30 arc-sec & ISRIC-World Soil Database \\
\hline & CLYPPT & & 30 arc-sec & ISRIC-World Soil Database \\
\hline & ORCDRC & & 30 arc-sec & ISRIC-World Soil Database \\
\hline & CRFVOL & & 30 arc-sec & ISRIC-World Soil Database \\
\hline & AWCh & & 30 arc-sec & ISRIC-World Soil Database \\
\hline $\begin{array}{l}\text { (3) Human } \\
\text { Influence }\end{array}$ & HII & human influence index & 30 arc-sec & $\begin{array}{c}\text { NASA Socioeconomic Data } \\
\text { and Applications Center } \\
\text { (SEDAC) }\end{array}$ \\
\hline
\end{tabular}

* The term quarter means the mean temperatures during the wettest three months of the year.

We used MaxEnt version 3.4.1k [43] to map the potential distribution of P. juliflora. The default settings were used, i.e., the maximum number of iterations (500), the replicated run type (cross-validation), and the output of the logistic. The accuracy of the models was tested by partitioning the data into $75 \%$ training and $25 \%$ testing subsets. Furthermore, the regularization setting was optimized to 2.5 to improve models' transferability across space and reduce the likelihood of models overfitting [44-47].

We built three different models: (1) model C (based on climate only), (2) model C+S (based on both climate and soil variables), (3) model $\mathrm{C}+\mathrm{S}+\mathrm{H}$ (based on climate, soil, and human influence variables). Then, we ran MaxEnt using occurrence records with each of the three models separately.

To evaluate the model accuracy, we calculated the True Skill Statistic (TSS), which is threshold dependent. Therefore, we used two settings in MaxEnt: write background predictions and the minimum training presence threshold (MTP). The latter is recommended to study invasive species distribution and risk assessment, providing a greater area of invasion suitability $[45,48]$.

The logistic output of habitat suitability provides the probability of $P$. juliflora, which ranges from 0 to 1. MaxEnt may give high-prediction values for environmental conditions outside the range of the target species. Hence, to avoid overestimation, we used only those pixels with values $\geq 0.5$ of the continuous suitability index, representing high invasion suitability $[9,43,49]$. The invasion suitability values were also extracted using the number of grid cells with suitability $\geq 0.5$ in each global terrestrial biome [50] (Figure 1 and Supplementary A, Table S5) using spatial join in ArcGIS 10.3 [36]. Then, we ranked the world terrestrial biomes based on the number of grid cells with a suitability score $\geq 0.5$ to determine the invasion risk level. 


\subsection{Model Performance and Evaluation}

The area under the curve (AUC) values of the receiver operating characteristic (ROC), helped us to compare the performance of the three models. The AUC is usually commonly used in evaluating multiple MaxEnt models. An AUC value closer to 1 indicates better model performance [42,51]. Sensitivity and True Skill Statistic (TSS) are also appropriate measures of the model accuracy to evaluate the model performance $[52,53]$. Unlike the AUC, sensitivity and TSS are threshold-dependent, and the latter accounts for both sensitivity and specificity, with values ranging from -1 to +1 . TSS is the sensitivity (percent of presences correctly predicted) + specificity (percent of absences correctly predicted) -1 of model predictions [52]. It is more likely to make a correct prediction when the species is present (means has higher sensitivity) [54].

Jack-knife tests and permutation importance provide an approach to evaluate the efficiency or predictive power and the relative importance of predictors where each variable is excluded in turn, and the model of each predictor in isolation is compared with a model comprising the remaining predictors [51]. The importance of the variables in the invasion suitability models was calculated by randomly permuting training presence and background data, i.e., permutation importance, which is an essential indicator for the strong model dependence on a particular variable [44,55]. The response curves show how environmental variables affect the prediction of invasion suitability. The curves show how the predicted probability of presence (invasion suitability) changes as each environmental variable is changed, keeping all the other environmental variables at their average values [56].

\section{Results}

\subsection{Model Performance}

All three models showed good fits and high performance in the prediction of the species distribution. All values of the sensitivity and AUC of the models were $>0.9$; meanwhile, the TSS values of the three models were larger than 0.5 ; meaning a good performance (Table 2). Furthermore, the AUC values of the models " $\mathrm{C}+\mathrm{S}$ " and " $\mathrm{C}+\mathrm{S}+\mathrm{H}$ " were slightly larger than those of " $\mathrm{C}$ " (Table 2). We represented the output of the climate and soil model $(\mathrm{C}+\mathrm{S})$ due to the higher relevant contribution and relative importance of the soil variables (Table 2) in the prediction of the species distribution.

Table 2. The relative contributions and importance of the climatic, edaphic, and human factors to the potential invasion risk of P. juliflora. The sensitivity, true skill statistic (TSS), and the area under the receiver-operating characteristic curve (AUC) indicate the performance or accuracy of the three models generated by MaxEnt. The most important variables and their values are shown in bold.

\begin{tabular}{|c|c|c|c|c|c|c|}
\hline \multirow{3}{*}{ Variable * } & \multicolumn{6}{|c|}{ Model } \\
\hline & \multicolumn{2}{|c|}{ Climate } & \multicolumn{2}{|c|}{ Climate + Soil } & \multicolumn{2}{|c|}{ Climate + Soil + Human } \\
\hline & $\begin{array}{c}\text { Percent } \\
\text { Contribution }\end{array}$ & $\begin{array}{l}\text { Permutation } \\
\text { Importance }\end{array}$ & $\begin{array}{c}\text { Percent } \\
\text { Contribution }\end{array}$ & $\begin{array}{l}\text { Permutation } \\
\text { Importance }\end{array}$ & $\begin{array}{c}\text { Percent } \\
\text { Contribution }\end{array}$ & $\begin{array}{l}\text { Permutation } \\
\text { Importance }\end{array}$ \\
\hline Bio4 & 49.6 & 37.2 & 43.1 & 42 & 36.5 & 47.7 \\
\hline PET & 15 & 4.6 & 10.7 & 0.4 & 15.2 & 0.3 \\
\hline Solar_rad & 14.7 & 17.8 & 3.8 & 2.2 & 2.4 & 2.7 \\
\hline AI & 13 & 19.5 & 0.3 & 1.3 & 0.9 & 1 \\
\hline Wind_spd & 4.2 & 1.7 & 0.6 & 0.7 & 2 & 1 \\
\hline Bio8 & 0.9 & 3.7 & 0.6 & 5.3 & 2.2 & 5.4 \\
\hline Bio9 & 1.5 & 14.2 & 1.8 & 21.1 & 1.4 & 15.9 \\
\hline Bio15 & 0.3 & 0.7 & 0 & 0 & 1.4 & 0 \\
\hline Bio16 & 0.8 & 0.5 & 0.3 & 0.4 & 0.5 & 1 \\
\hline PHIHOX & - & - & 25.6 & 17.5 & 23.4 & 18.9 \\
\hline CEC & - & - & 0.8 & 0.9 & 3.1 & 1.4 \\
\hline CLYPPT & - & - & 9.3 & 5.9 & 7.7 & 3.5 \\
\hline ORCDRC & - & - & 0.6 & 0.3 & 0.6 & 0.5 \\
\hline
\end{tabular}


Table 2. Cont.

\begin{tabular}{|c|c|c|c|c|c|c|}
\hline \multirow{3}{*}{ Variable * } & \multicolumn{6}{|c|}{ Model } \\
\hline & \multicolumn{2}{|c|}{ Climate } & \multicolumn{2}{|c|}{ Climate + Soil } & \multicolumn{2}{|c|}{ Climate + Soil + Human } \\
\hline & $\begin{array}{c}\text { Percent } \\
\text { Contribution }\end{array}$ & $\begin{array}{l}\text { Permutation } \\
\text { Importance }\end{array}$ & $\begin{array}{c}\text { Percent } \\
\text { Contribution }\end{array}$ & $\begin{array}{l}\text { Permutation } \\
\text { Importance }\end{array}$ & $\begin{array}{c}\text { Percent } \\
\text { Contribution }\end{array}$ & $\begin{array}{l}\text { Permutation } \\
\text { Importance }\end{array}$ \\
\hline CRFVOL & - & - & 0.3 & 0.3 & 0.4 & 0.3 \\
\hline AWCh & - & - & 2.2 & 1.5 & 2.3 & 0.3 \\
\hline HII & - & - & - & - & 0.1 & 0.1 \\
\hline AUC & \multicolumn{2}{|c|}{0.947} & \multicolumn{2}{|c|}{0.958} & \multicolumn{2}{|c|}{0.958} \\
\hline Sensitivity & \multicolumn{2}{|c|}{1} & \multicolumn{2}{|c|}{1} & \multicolumn{2}{|c|}{0.998} \\
\hline TSS & \multicolumn{2}{|c|}{0.589} & \multicolumn{2}{|c|}{0.559} & \multicolumn{2}{|c|}{0.585} \\
\hline
\end{tabular}

* Bio4: temperature seasonality (standard deviation * 100); PET: potential evapotranspiration $(\mathrm{mm})$; Solar_rad: solar radiation $\left(\mathrm{kJ} \mathrm{m}^{-2}\right.$ day $\left.^{-1}\right)$; AI: aridity index; Wind_spd: wind speed $\left(\mathrm{m} \mathrm{s}^{-1}\right)$; Bio8: mean temperatures of the wettest quarter $\left({ }^{\circ} \mathrm{C}\right)$; Bio9: Mean temperature of the driest quarter $\left({ }^{\circ} \mathrm{C}\right)$; Bio15: precipitation seasonality $(\mathrm{C}$ of $\mathrm{V})$; Bio16: precipitation of wettest quarter (mm), $\mathrm{PHIHOX}$ : soil $\mathrm{pH} \times 10$ in $\mathrm{H}_{2} \mathrm{O}$; CEC: cation exchange capacity in cmolc/ $\mathrm{kg}$; CLYPPT: soil texture fraction clay in percent; ORCDRC: soil organic carbon content in $\mathrm{g}$ per kg; CRFVOL: coarse fragments volumetric in percent; AWCh: Available soil water capacity; HII: human influence index.

\subsection{Global Distribution and Potential Invasion Suitability of P. juliflora}

Most of the occurrence records (99\%) were located in the arid and hyper-arid regions (Aridity index $<0.2$, Supplementary A, Table S2), which are located mainly in the tropical and subtropical biomes (Figure 1). The invasion of suitable areas was reduced when soil or human influence variables were incorporated into the model (Figure 2A-C). Moreover, the human influence factor was contributed only by $0.1 \%$ to the potential distribution, indicating that human influence is not an important variable to the potential invasion suitability.

\subsection{P. juliflora Invasion Suitability and Environmental Variables}

Based on the percent contribution of the predictor variables that were generated by MaxEnt model $\mathrm{C}+\mathrm{S}$, the most important factors defining the potential global distribution of $P$. juliflora were temperature seasonality (Bio4, 43.1\%), PET (10.7\%), soil pH (25.6\%), and soil clay texture fraction $(9.3 \%$ ) (Table 2 ). The responses of the remaining variables that showed less importance were shown in Supplementary B, Figure S2. Regarding the permutation importance, the maximum influence on the potential invasion suitability was for temperature seasonality (Bio4, probability of the presence was $42 \%$ ), followed by the temperature of the driest quarter (Bio9, $21.1 \%)$, then soil $\mathrm{pH}(17.5 \%)$, and finally by soil clay texture fraction $(5.9 \%)$.

The probability of the presence of $P$. juliflora decreased in response to temperature seasonality (Bio4), gradually up to a variation of $13 \%$ (Figure 3). The likelihood of P. juliflora presence increased gradually with the increase of the driest quarter temperature (Bio9) at a suitable range (approximately $21-23^{\circ} \mathrm{C}$ ); the optimal value is approximately $22^{\circ} \mathrm{C}$. Above $23{ }^{\circ} \mathrm{C}$, the invasion suitability of P. juliflora showed a gradual decline (Figure 3).

Regarding the climate-based model (Model C), the invasion suitability decreases gradually with the increase of aridity index up to an approximate value of 0.42 (semi-arid conditions) above which the suitability is very low and becomes constant (Supplementary B, Figure S2). With the increase of solar radiation, the invasion suitability increases up to an approximated maximum value of $19,500 \mathrm{~kJ} \mathrm{~m}^{-2}$ day $^{-1}$, above which a sharp decline of the logistic suitability occurs (Supplementary B, Figure S2). The overall response of invasion suitability prediction for the wind speed is positive above $18 \mathrm{~m} \mathrm{~s}^{-1}$; the logistic invasion suitability increases with the increase of wind speed up to the maximum approximated speed of $120 \mathrm{~m} \mathrm{~s}^{-1}$ (Supplementary B, Figure S2). 

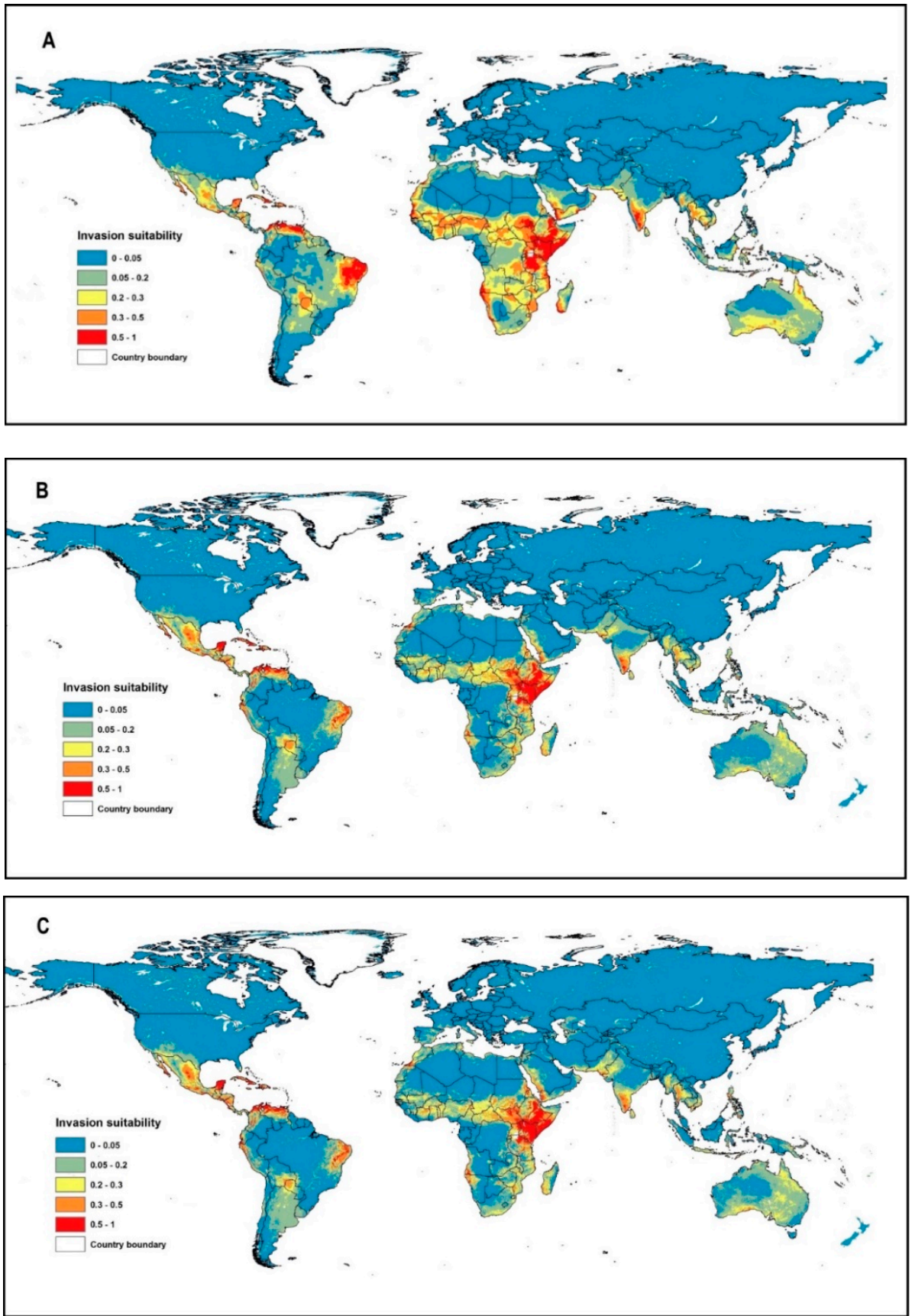

Figure 2. Global invasion risk (potential habitat suitability) of P. juliflora according to the three different models: (A) Climate model, (B) Climate and soil model (C) Climate, soil, and human influence mode.

Regarding the soil suitability for the occurrence of $P$. juliflora, the model " $\mathrm{C}+\mathrm{S}$ " results showed that soil $\mathrm{pH}$ and soil clay fraction were the key soil factors determining the distribution of this species along with the climatic factors mentioned above. The potential invasion suitability increases with soil $\mathrm{pH}$; the most excellent presence probability was at an approximate $\mathrm{pH}$ of 9.2 (Figure 3). This result suggests that $P$. juliflora prefers alkaline habitats. There is a sharp increase in the presence probability of $P$. juliflora with the increase in clay content up to $22 \%$, after which there is a gentle linear increase of the occurrence till $70 \%$ (Figure 3). Moreover, there is a linear increase in the occurrence suitability of P. juliflora with the increase in the available soil water capacity from $2 \%$ up to $11.5 \%$; above that; there is no change (Supplementary B, Figure S2). 

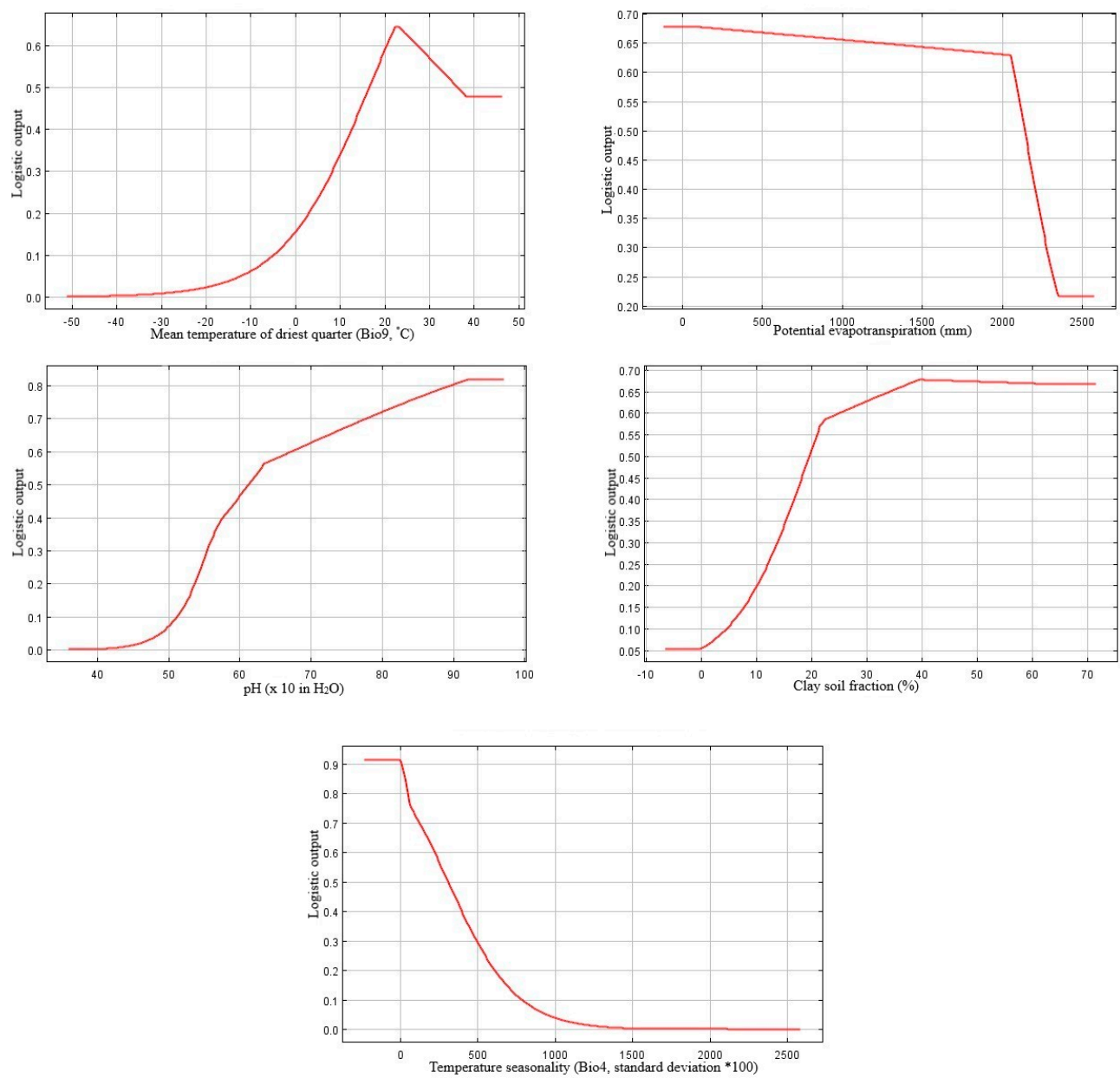

Figure 3. Response curves of the most influential climatic and edaphic predictors generated by MaxEnt (Climate + Soil model). Bio4: temperature seasonality (standard deviation $\left.{ }^{*} 100\right)$; Bio9: Mean temperature of the driest quarter $\left({ }^{\circ} \mathrm{C}\right)$; PET: potential evapotranspiration; PHIHOX: soil $\mathrm{pH} \times 10$ in $\mathrm{H}_{2} \mathrm{O}$; CEC: CLYPPT: soil texture fraction clay.

\subsection{Potential Invasion Risk at Biom Level}

The invasion suitability of $P$. juliflora varied remarkably among the main biome types (Figure 4). The highest invasion suitability is in the tropical and subtropical grasslands, savannahs, and shrublands (TSGSS, 52,896 grid cells), followed by the deserts and xeric shrublands (DXS, 23,713) (Figure 4, and Supplementary A, Table S5). The tropical and subtropical moist and dry broadleaf forests (TSMF and TSDF) have moderate chances of being among high invasion risk biomes. Furthermore, there is a lower chance of flooded grasslands and savannahs (FGS) and mangroves among invaded high-risk biomes (Figure 4). The biomes that have the lowest chance for invasion are Mediterranean forests, woodlands, and scrub (MFWS), montane grasslands and shrublands (MGS), tropical and subtropical coniferous forests (TSCF), and lakes. It is worth noting that the global biomes showing high potential invasion suitability fell in the order: TSGSS $>$ DXS $>$ TSMF $>$ TSDF $>$ FGS $>$ mangroves $>$ MFWS $>$ MGS $>$ TSCF $>$ lakes (Figure 4). 


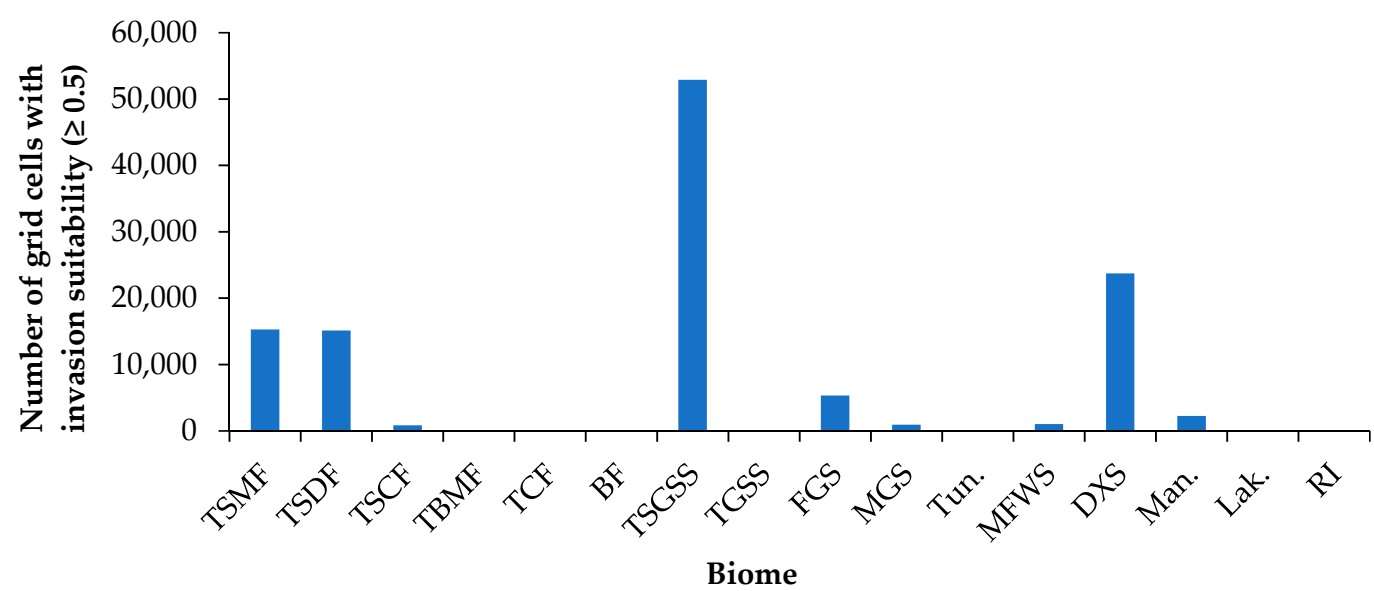

Figure 4. Invasion risk to global biomes with high habitat suitability $(\geq 0.5)$ for the invasion of $P$. juliflora. Abbreviations: TSMF = Tropical and Subtropical Moist Broadleaf Forests; TSDF = Tropical and Subtropical Dry Broadleaf Forests; TSCF = Tropical and Subtropical Coniferous Forests; TBMF = Temperate Broadleaf and Mixed Forests; TCF = Temperate Conifer Forests; BF = Boreal Forests $/$ Taiga; TSGSS = Tropical and subtropical grasslands, savannahs, and shrublands; TGSS = Temperate Grasslands, Savannahs, and Shrublands; FGS = Flooded Grasslands and Savannahs; MGS = Montane Grasslands and Shrublands; Tun. = Tundra; MFWS = Mediterranean Forests, Woodlands, and Scrub; DXS = Deserts and Xeric Shrublands; Man. = Mangroves; Lak. = Lakes; RI = Rock and Ice.

\section{Discussion}

\subsection{Potential Distribution of P. juliflora and Invasion Suitability Models}

Climate is a key factor in determining the species capabilities to conquer and invade new areas $[7,29]$. However, other non-climatic factors are as important as the climate in influencing species abilities to invade new areas, including physical and chemical properties of soils, moisture availability, topographic features, and human-induced disturbances [35,57]. The earlier studies that assessed the invasive abilities of $P$. juliflora to new range depended mainly on climate [1,7]. For example, EPPO [9] had used MaxEnt in an ensemble modelling with other models to explain the potential distribution of $P$. juliflora. MaxEnt model showed high accuracy with similar contribution and response of the climatic moisture index (18\%) [9], and this agrees to our results of the contribution and response of the evapotranspiration (15\%). On the other hand, the model also showed high contribution of the temperature of the coldest month (64\%), but this differ from our results which revealed that temperature seasonality $(49.6 \%)$. This difference may be attributed to using different predictors, but our study showed more precise predictions of the invasion suitability because we built our best model on climate and soil. Furthermore, we selected the relevant variables based on the occurrence data of the species where it was distributed in the arid and hyper-arid regions, so temperature of the driest quarter and temperature seasonality are more relevant bioclimatic variables than other variables. However, incorporating the edaphic factors in our models showed a higher performance and produced more accurate predictions. The suitable areas for invasion with $P$. juliflora were reduced when soil or human influence variables were incorporated into the model. Provided that suitable climatic conditions are available, edaphic factors can set the ecological boundaries that restrict species distributions and determine community composition [58]. Adding the soil variables, particularly soil $\mathrm{pH}$ and clay fraction, showed high relevant contribution and relative importance in the prediction of $P$. juliflora distribution. For example, the increase in soil $\mathrm{pH}$ (i.e., alkalinity) markedly increased the probability of the presence of $P$. juliflora. However, the probability decreased above $\mathrm{pH}$ 9.0. It has been reported that the suitability of soil substrates for germination and seedling growth of $P$. juliflora was significantly reduced above $\mathrm{pH}$ of 9.0 [58]. Soil texture, $\mathrm{pH}$, and moisture content are important ecological conditions that significantly influenced native and invasive species distribution in the arid and semi-arid ecosystem [59]. Other biological factors that can play a significant role locally 
in the invasion potential, which was not accounted for at the global level, are livestock and birds in long-distance seed-dispersal $[60,61]$.

In general, non-climatic factors related to human-induced activities such as land-use changes, the establishment of road networks, transportation, etc. facilitate introducing species to new areas and increase invasion susceptibility [62]. In our study, however, the human influence indicator did not contribute significantly to the models' performance predicting the distribution of $P$. juliflora at the global scales. The significance of the human activities and the associated disturbances in influencing the potential invasion suitability of $P$. juliflora could be more significant at a local rather than a global scale. For example, Abbas et al. [34] found that the probability of P. juliflora was higher in areas closer to roads. The Human Influence Index (HII) used in the current study as an indicator of human disturbances on the natural ecosystems was derived based on measures urbanization level measures, accessibility by transportation means, degree of landscape modification, and access to electricity and power networks. The elements of the HII are higher in the developed countries that are mostly located outside the range of occurrence of P. juliflora, whereas areas that are suitable climatically to the occurrence of $P$. juliflora are located in the arid and hyper-arid developing countries ( $99 \%$ of the occurrence records); mainly in the southern hemisphere. Therefore, the index did not contribute much in connecting human-induced disturbances to the invasion potential of $P$. juliflora at the global scale.

\subsection{Environmental Drivers Best Explain the Invasion Suitability of P. juliflora}

Our results of the response curves revealed that the increase in temperature of the driest season would increase the invasion risk or expansion of $P$. juliflora. The projected global increase by about $1-3^{\circ} \mathrm{C}$ in temperature by the end of this century would trigger shifts in arid/humid climate zones worldwide [63]. The projected conversion of some areas that are currently considered humid and semi-arid into arid zones due to global warming will provide more suitable areas for the invasion of $P$. juliflora [64,65]. In addition, climate scenarios projected an increase in the temperatures of the driest seasons and in the aridity of many parts of the humid and semi-arid regions, which again could create more suitable areas for the invasion of $P$. juliflora under climate change.

Our study's outcomes suggested that the optimum temperature for the logistic potential distribution or presence suitability was $22^{\circ} \mathrm{C}$. Earlier studies have revealed the ability of $P$. juliflora to withstand temperatures up to $50^{\circ} \mathrm{C}[10,14,15]$. Moreover, the increase in temperature was associated with increases in the germination rate $[8,66]$. The accumulation of a high density of seeds (ca. 60 million seeds ha ${ }^{-1} \mathrm{yr}^{-1}$ ) in the soils can enable P. juliflora to regenerate at higher temperatures successfully and under light conditions [66-68]. It is worth noting that temperature interacted with light to regulate seed germination of P. juliflora, provided that moisture is available. This indicates that disturbance could bring seeds to the upper layers, where both light and temperature conditions are suitable for germination [69]. Livestock and flooding are two crucial dispersal agents of seeds; both enhance seed germination and seedling establishment and facilitate the expansion and invasion of $P$. juliflora [70]. According to the plant-soil feedbacks hypothesis, both leguminous plant and microbes affect each other to improve soils' physical and chemical properties [71]. P. juliflora can improve soil properties through soil microorganisms, living free in soils or forming a symbiotic relationship in the plants' nodules. Besides, soil microflora can increase litter decomposition that increases clay fraction and water holding capacity. According to our models, the increase in soil moisture and clay fraction can enhance the invasive ability of $P$. juliflora. The amelioration of soil characters by P. juliflora is particularly important in sandy soils in arid biomes, which are characterized by lower fertility and higher $\mathrm{pH}[10,14]$. Soil fertility, including $\mathrm{N}$, was significantly greater beneath and around $P$. juliflora canopies than in soils away from them [14]. 


\subsection{Potential Invasion Risk}

\subsubsection{At the National Level}

Ninety percent of the total world countries where P. juliflora currently occurs showed high suitability of invasion risk. This finding is supported by earlier studies [1,9].Surveys and monitoring of the population dynamic of this invasive species are needed, especially in countries with no current records. Moreover, there should be preventive approaches for the arrival and propagation of this invasive species, especially in countries with no current records and those predicted to achieve high invasion under climate change [29].

Livestock and wildlife animals help in seed dispersal and germination of $P$. juliflora by increasing chemical and physical scarifications for seeds that have deep physical dormancy [69,72]. For example, in arid and semi-arid north Mediterranean African regions, camels and sheep are common domestic animals that can potentially disperse the seeds of P. juliflora and can help in the invasion expansion along animals' routes [72,73]. In Egypt, these animals disperse P. juliflora along Gebel Elba National Park, the southeast part of the Eastern Desert on the border between Egypt and Sudan [72]. Our study defined this region among the threatened regions by the invasion of P. juliflora (Figure 2B). Therefore, animal grazing could help expand P. juliflora invasion in the southern part of Egypt. Currently, the middle and northern parts of Egypt are not infested with P. juliflora. However, these regions and most of the northern regions of the Mediterranean countries could get considerably warmer by 2050 under the moderate and high climatic emission scenarios (RCP 4.5 and RCP 8.5) [29]. Accordingly, both climate change and seed dispersal from south to north, mainly by livestock, could result in the invasion of northern regions of the African counties with $P$. juliflora. It is recommended to monitor and remove any small young populations that appear along animals' routes in the northern region. Similarly, P. juliflora was not considered invasive in Spain until 2014 [1]. This was recently observed in the frost-free coastal and low-lying inland areas of Spain [9], which strongly supports our prediction that Spain is at high invasion risk.

African countries are at high risk of invasion, e.g., Kenya, Ethiopia, Somalia, South Sudan, and Sudan, which introduced this species for economic purposes, mainly for firewood, timber, fodder, and other uses [26,35]. The species provide over $70 \%$ of firewood, mainly in rural India and parts of its urban areas $[1,74]$. The trade-in P. juliflora products were valued as above 1.5 million USD in some villages in Kenya [75]. However, after the introduction, $P$. juliflora became invasive and threaten ecosystem services and human health [11]. With the expected climate change and increasing human activities, P. juliflora might become more invasive. Therefore, the management and control of $P$. juliflora invasion may pose challenges in some of the affected countries due to some socio-economic factors that facilitate the expansion of P. juliflora. Among the socio-economic factors are the economic dependence of local communities in certain nations, especially in developing countries, on the species for production and marketing of charcoal and firewood [1].

In Africa, one of the most critical vital barriers for the effective management of P. juliflora species is the lack of strategic planning and prioritization [76]. Adaptive measures to control the invasion of $P$. juliflora vary among the nations and need to consider the ecological settings plus the socio-economic needs. There are huge costs associated with the invasion of $P$. juliflora, such as a reduction in ecosystem services and species diversity. However, this plant provides numerous goods and services, including, for example, the production of honey, edible exudates, gums, fibers, tannins, bio-pesticides, medicinal compounds, biochar, and several forms of biofuels [77,78]. This argued decision-makers to adopt a new cost-effective management strategy depends on the control of $P$. juliflora through sustainable utilization for the control [79]. However, efficient management of the species invasion in countries predicted as edges of high potential invasion may require cross-boundary endeavors for controlling its extension to new regions, mainly when livestock disperse seeds across the borders. Therefore, the findings of the current study would help in strategic planning and prioritization of the invaded land areas based on the potential invasion suitability (i.e., invasion risk level). The accurate maps of invasion 
suitability for each country provide a promising tool to different stakeholders for the strategic planning towards effective management of this invasive species.

It has been reported that $P$. juliflora is more aggressive in its introduced range as compared to its native range [80]. In its native range, $P$. juliflora coexists with large numbers of other native species; its canopies have strong facilitative effects on neighbor plants [80]. However, $P$. juliflora has interfering effects on the associated plants in its non-native range. For example, this species completely suppressed the native flora in the arid deserts of the UAE, despite it significantly improved the physical and chemical properties of the soil beneath it $[14,15]$. However, according to our results, the presence probability of P. juliflora is higher in some non-native ranges (e.g., Kenya, Ethiopia) than in all countries within the native range. It seems that $P$. juliflora acquired adaptive ecological features enable it to invade the non-native range and determinately affect its ecosystem services and species diversity $[9,80]$. The detrimental effects of $P$. juliflora in the non-native range further emphasize the importance of adopting an efficient management strategy for controlling this plant through sustainable utilization [79].

\subsubsection{At the Biome Level}

The global biomes showed remarkable variation in the suitability of the invasion by P. juliflora. The tropical and subtropical biomes exhibited the highest suitability compared to other biomes. This can be attributed to the native range of $P$. juliflora, which is the subtropical regions of Central America, northern South America, and the Caribbean $[8,80,81]$. The tropical and subtropical grasslands, savannahs, and shrublands exhibited the highest suitability, followed by the Deserts and Xeric Shrublands. Other studies e.g., Heshmati et al. [29], concluded that the species pose a higher risk for expansion in these biomes, particularly the Mediterranean region, west and central Asia, North African, and North America. The variation in the invasion suitability of $P$. juliflora in the different global biome types, is due to the broad ecological amplitude, which makes this specie a successful invader in different biomes $[19,20]$.

Our results indicate a high-risk chance for the invasion of $P$. juliflora in the Mediterranean region, especially North African countries and South Europe, such as Spain (Figure 2B). The most critical factor limiting the potential geographical distribution of P. juliflora is the minimum temperatures during winter [9]. The level, duration, and frequency of frosts limit the reproduction and growth of this species [1,9]. Severe frost can cause stem and mortality of P. juliflora in countries with cold weather [8]. Therefore, there is a doubt about $P$. juliflora' occurrence in countries of Mediterranean climates, such as Morocco, Algeria, Tunisia, Libya, and Egypt [8,9]. P. juliflora was introduced to Spain for vegetation trials in a single location and showed naturalization, but no invasion signs [1]. However, future global warming in the Mediterranean region is expected to exceed global rates by $25 \%$ [82]. Besides, temperature increase has been projected to range between $2{ }^{\circ} \mathrm{C}$ and $4{ }^{\circ} \mathrm{C}$ by the 2080s in Southern Europe with a chance of short or no frost seasons in the Balkans [83]. Such climatic change would increase the chance of the invasive risk of P. juliflora to the Mediterranean region.

Also, P. juliflora has several adaptive features that enable it to grow well and even flourish in very poor dry hot desert habitats that are commonly considered to be unsuitable for the dominance of many other plant species [11-13,74] For example, the deep taproot of this species allows it to secure its water requirements during dry seasons and hence to invade the dry arid lands [74]. In addition, P. juliflora was able to tolerate high sun intensity and temperatures of the hyper-arid environment of the Gulf region by avoiding permanent damage of the photosynthetic apparatus that happened by lowering PSII efficiency and dissipating extra light energy through the increase of non-photochemical quenching [12]. Furthermore, the intrinsic water-use efficiency of $P$. juliflora was significantly greater than in the congeneric native P. cineraria in the arid deserts [13]. According to our models, higher temperatures, soil alkalinity, and a higher ratio of fine soil particles accelerate the invasion of P. juliflora. In the Arab Gulf deserts, the high temperatures coupled with soil alkalinity 
of the calcareous soils (i.e., higher $\mathrm{pH}$ ) enhanced the invasion ability of $P$. juliflora invading the region at an alarming rate $[10,15,84]$. Notably, the growth of $P$. juliflora trees adds more organic contents, which increases the proportion of fine soil particles [10,14]. Such a change in soil texture would exacerbate the invasion rate of $P$. juliflora in such arid deserts. Moreover, $P$. juliflora gains more advantages over its native competitors, making it spread faster in the infested countries $[12,13]$. The investigations conducted in the Sultanate of Oman, one of the top threatened countries in the desert biome according to our models, indicated that $P$. juliflora germinated faster and greater, even under stress conditions, such as heat and drought, as compared with its native congener P. cineraria [84]. In addition, P. juliflora produces allelochemicals that suppress seed germination and growth, and even survival, of other species growing in its vicinity $[10,15,22,66,85]$.

The results predicted the dry shrublands and grasslands biomes to be more suitable for P. juliflora than moist forest biomes. Prosopis juliflora has a more competitive advantage over other native woody plants in arid and semi-arid lands due to its ability to proficiently access and abstract underground water via its efficient root system [74]. Moreover, adult plants of P. juliflora have greater resistance to fire than other woody species [86]. Furthermore, the ability of $P$. juliflora to replace native species of the same lifeform and niche [87] is higher in arid regions compared to other moist ecosystems.

Climate change is the key driver in shaping $P$. juliflora distribution patterns continentally and may lead to a shift in biomes boundaries [88]. Moreover, climate change may increase the risk of the proliferation of invasive species [7]. Some biomes are believed to be of relatively higher susceptibility to climate change consequences, especially the tropical rainforest, the deciduous forest, steppe, and grasslands of Asia and North and South America [89]. The ecological sensitivity of these regions will exacerbate the risk of invasion by P. juliflora. However, local conditions and factors, particularly soil properties, the substrate's nature, the existence of natural enemies, and biotic interactions, will define the limits for the species invasion [7].

\section{Conclusions}

Species distribution models that incorporate edaphic factors and climate to project the potential distribution, invasion risk or expansion of $P$. juliflora provide a more precise estimate of the potential susceptible areas to the species invasion. The potential invasion risk of $P$. juliflora increases with the increase of temperature of dry seasons along with soil alkalinity and clay fractions. This confirms that hot arid and semi-arid lands are currently at the highest risk of invasion or expansion than other moist biomes. The top threatened countries that exhibited high invasion suitability are mostly developing countries, most of which are located in Africa. The introduction of the species in some of these countries was for economic purposes, which may pose challenges for control actions. Cross-boundary endeavors for controlling P. juliflora expansion to new regions, particularly in countries predicted as edges of high potential invasion, are required to efficiently manage the species invasion, particularly in the tropical and subtropical broadleaf-forests and shrublands. Finally, logical directions of future research on the ranking of world countries with invasion risk based on the area and number of the country's protected areas with high invasion risk. This would provide great insights into conservation planning.

Supplementary Materials: The following are available online at https: / www.mdpi.com/2079-7 737/10/3/203/s1, Table S1: Occurrence data, Table S2: Environmental Data, Table S3: Climate correlations, Table S4: Soil correlations, Table S5: Biome data; Figure S1: Jack-knife test for evaluating the relative importance of predictor variables for Prosopis juliflora globally (generated by MaxEnt climate + soil model). Figure S2: Response curves of the less important climatic and edaphic predictor variables of Prosopis juliflora generated by MaxEnt (Climate + Soil model).

Author Contributions: A.E.-K. and M.A.D.: Conceptualization. M.A.D.: software, validation, and formal analysis. M.A.D., A.E.-K. and M.A.E.-S.: resources, data curation, and visualization. A.E.-K., M.A.D., M.A.E.-S., M.W.A.H., W.A.H., and T.K.: writing (all stages of the manuscript). A.E.-K.: 
project administration and supervision. All authors have read and agreed to the published version of the manuscript.

Funding: The work was supported by a research project (ID: 150428) for A.E.-K. funded by both Sharjah Research Academy and the Research Office of the University of Sharjah. The author M.A.ElSheikh extends his appreciation to the Researchers Supporting Project Number (RSP-2020/182), King Saud University, Riyadh, Saudi Arabia.

Data Availability Statement: Data are contained within the article or Supplementary Material.

Acknowledgments: Authors thank Bikram Pandey (Chengdu Institute of Biology, Chinese Academy of Sciences, China) for helping during downloading of the occurrence data. The work was supported by a research project (ID: 150428) for A.E.-K. funded by both Sharjah Research Academy and the Research Office of the University of Sharjah. The author M.A.El-Sheikh extends his appreciation to the Researchers Supporting Project Number (RSP-2020/182), King Saud University, Riyadh, Saudi Arabia.

Conflicts of Interest: The authors declare no conflict of interest.

\section{References}

1. Shackleton, R.T.; Le Maitre, D.C.; Pasiecznik, N.M.; Richardson, D.M. Prosopis: A global assessment of the biogeography, benefits, impacts and management of one of the world's worst woody invasive plant taxa. AoB Plants 2014, 6, 1-18. [CrossRef]

2. Liu, Y.; Oduor, A.M.O.; Zhang, Z.; Manea, A.; Tooth, I.M.; Leishman, M.R.; Xu, X.; Van Kleunen, M. Do invasive alien plants benefit more from global environmental change than native plants? Glob. Chang. Biol. 2017, 23, 3363-3370. [CrossRef]

3. Moodley, D.; Geerts, S.; Richardson, D.M.; Wilson, J.R.U. Different traits determine introduction, naturalization and invasion success in woody plants: Proteaceae as a test case. PLoS ONE 2013, 8, e75078.

4. Shackleton, R.T.; Shackleton, C.M.; Kull, C.A. The role of invasive alien species in shaping local livelihoods and human well-being: A review. J. Environ. Manag. 2019, 229, 145-157. [CrossRef] [PubMed]

5. Wardle, D.A. Experimental demonstration that plant diversity reduces invasibility-evidence of a biological mechanism or a consequence of sampling effect? Oikos 2001, 95, 161-170. [CrossRef]

6. Pyšek, P.; Jarošík, V.; Hulme, P.E.; Pergl, J.; Hejda, M.; Schaffner, U.; Vilà, M. A global assessment of invasive plant impacts on resident species, communities and ecosystems: The interaction of impact measures, invading species' traits and environment. Glob. Chang. Biol. 2012, 18, 1725-1737. [CrossRef]

7. Sintayehu, D.W.; Egeru, A.; Ng, W.; Cherenet, E. Regional dynamics in distribution of Prosopis juliflora under predicted climate change in Africa. Trop. Ecol. 2020, 61, 437-445. [CrossRef]

8. Pasiecznik, N.M.; Felker, P.; Harris, P.J.C.; Harsh, L.; Cruz, G.; Tewari, J.C.; Cadoret, K.; Maldonado, L.J. The Prosopis julifloraProsopis pallida Complex: A Monograph; HDRA: Coventry, UK, 2001; Volume 172.

9. $\quad$ EPPO. Pest Risk Analysis for Prosopis juliflora; EPPO: Paris, France, 2018.

10. El-Keblawy, A.; Al-Rawai, A. Impacts of the invasive exotic Prosopis juliflora (Sw.) DC on the native flora and soils of the UAE. Plant Ecol. 2007, 190, 23-35. [CrossRef]

11. Hussain, M.I.; Shackleton, R.T.; El-Keblawy, A.; Del Mar Trigo Pérez, M.; González, L. Invasive Mesquite (Prosopis juliflora), an allergy and health challenge. Plants 2020, 9, 141. [CrossRef]

12. Hussain, M.I.; El-Keblawy, A. Surface canopy position determines the photosystem II photochemistry in invasive and native Prosopis Congeners at Sharjah Desert, UAE. Forests 2020, 11, 740. [CrossRef]

13. Hussain, M.I.; El-Keblawy, A.; Mitterand Tsombou, F. Leaf age, canopy position, and habitat affect the carbon isotope discrimination and water-use efficiency in three C3 Leguminous Prosopis species from a hyper-arid climate. Plants $2019,8,402$. [CrossRef]

14. Slate, M.L.; Tsombou, F.M.; El-Keblawy, A.A.; Callaway, R.M. Exotic Prosopis juliflora suppresses understory diversity and promotes agricultural weeds more than a native congener. Plant Ecol. 2020, 221, 659-669. [CrossRef]

15. El-Keblawy, A.; Abdelfatah, M.A. Impacts of native and invasive exotic Prosopis congeners on soil properties and associated flora in the arid United Arab Emirates. J. Arid Environ. 2014, 100, 1-8. [CrossRef]

16. Koech, O.K.; Kinuthia, R.N.; Wahome, R.G.; Choge, S.K. Effects of Prosopis juliflora seedpod meal supplement on weight gain of weaner Galla goats in Kenya. Res. J. Anim. Sci. 2010, 4, 58-62. [CrossRef]

17. Brown, J.H.; Sax, D.F. An essay on some topics concerning invasive species. Austral Ecol. 2004, 29, 530-536. [CrossRef]

18. Luque, G.M.; Bellard, C.; Bertelsmeier, C.; Bonnaud, E.; Genovesi, P.; Simberloff, D.; Courchamp, F. The 100th of the world's worst invasive alien species. Biol. Invasions 2014, 16, 981-985. [CrossRef]

19. Pasiecznik, N.M.; Weerawardane, N.D.R. Invasion of the exotic tree species Prosopis juliflora Sw.(DC) in Puttalam District-its spread, new records, and the need for action. Sri Lankan For. 2011, 32, 43-50.

20. CABI. Prosopis juliflora. In Invasive Species Compendium; CABI: Wallingford, UK, 2017.

21. Jurand, B.S.; Abella, S.R. Soil seed banks of the exotic annual grass Bromus rubens on a burned desert landscape. Rangel. Ecol. Manag. 2013, 66, 157-163. [CrossRef] 
22. Shiferaw, H.; Teketay, D.; Nemomissa, S.; Assefa, F. Some biological characteristics that foster the invasion of Prosopis juliflora (Sw.) DC. at Middle Awash Rift Valley Area, north-eastern Ethiopia. J. Arid Environ. 2004, 58, 135-154. [CrossRef]

23. Abdulahi, M.M.; Ute, J.A.; Regasa, T. Prosopis juliflora 1: Distribution, impacts and available control methods in Ethiopia. Trop. Subtrop. Agroecosyst. 2017, 20, 75-89.

24. Qiao, H.; Lin, C.; Jiang, Z.; Ji, L. Marble algorithm: A solution to estimating ecological niches from presence-only records. Sci. Rep. 2015, 5, 1-10. [CrossRef]

25. Fitzpatrick, M.C.; Gove, A.D.; Sanders, N.J.; Dunn, R.R. Climate change, plant migration, and range collapse in a global biodiversity hotspot: The Banksia (Proteaceae) of Western Australia. Glob. Chang. Biol. 2008, 14, 1337-1352. [CrossRef]

26. Wang, H.-H.; Wonkka, C.L.; Treglia, M.L.; Grant, W.E.; Smeins, F.E.; Rogers, W.E. Incorporating local-scale variables into distribution models enhances predictability for rare plant species with biological dependencies. Biodivers. Conserv. 2019, 28, 171-182. [CrossRef]

27. Austin, M.P. Spatial prediction of species distribution: An interface between ecological theory and statistical modelling. Ecol. Modell. 2002, 157, 101-118. [CrossRef]

28. Wakie, T.T.; Evangelista, P.H.; Jarnevich, C.S.; Laituri, M. Mapping current and potential distribution of non-native Prosopis juliflora in the Afar region of Ethiopia. PLoS ONE 2014, 9, 3-11. [CrossRef] [PubMed]

29. Heshmati, I.; Khorasani, N.; Shams-Esfandabad, B.; Riazi, B. Forthcoming risk of Prosopis juliflora global invasion triggered by climate change: Implications for environmental monitoring and risk assessment. Environ. Monit. Assess. 2019, 191. [CrossRef]

30. Regos, A.; Gagne, L.; Alcaraz-Segura, D.; Honrado, J.P.; Domínguez, J. Effects of species traits and environmental predictors on performance and transferability of ecological niche models. Sci. Rep. 2019, 9, 1-14. [CrossRef] [PubMed]

31. Russo, S.E.; Davies, S.J.; King, D.A.; Tan, S. Soil-related performance variation and distributions of tree species in a Bornean rain forest. J. Ecol. 2005, 93, 879-889. [CrossRef]

32. Wan, J.-Z.; Wang, C.-J. Expansion risk of invasive plants in regions of high plant diversity: A global assessment using 36 species. Ecol. Inform. 2018, 46, 8-18. [CrossRef]

33. de Souza Nascimento, C.E.; da Silva, C.A.D.; Leal, I.R.; de Souza Tavares, W.; Serrão, J.E.; Zanuncio, J.C.; Tabarelli, M. Seed germination and early seedling survival of the invasive species Prosopis juliflora (Fabaceae) depend on habitat and seed dispersal mode in the Caatinga dry forest. PeerJ 2020, 8, e9607. [CrossRef]

34. Abbas, A.M.; Soliman, W.S.; Mansour, A.; Taher, E.; Hassan, I.N.; Mahmoud, M.; Abdelkareem, M. Predicting the spatial spread of invasive Prosopis juliflora (SW.) DC along environmental gradients in Gabel Elba National Park, Egypt. Int. J. Sci. Eng. Res 2016, 7, 596-599.

35. Mod, H.K.; Scherrer, D.; Luoto, M.; Guisan, A. What we use is not what we know: Environmental predictors in plant distribution models. J. Veg. Sci. 2016, 27, 1308-1322. [CrossRef]

36. ESRI (Environmental Systems Research Institute). 2014 ArcGIS®Desktop Help 10.3 Geostatistical Analyst. Available online: https:/ / desktop.arcgis.com/en/arcmap/10.3 (accessed on 1 November 2020).

37. Fick, S.E.; Hijmans, R.J. WorldClim 2: New 1-km spatial resolution climate surfaces for global land areas. Int. J. Climatol. 2017, 37, 4302-4315. [CrossRef]

38. Trabucco, A.; Zomer, R.J. Global aridity index (global-aridity) and global potential evapo-transpiration (global-PET) geospatial database. CGIAR Consort. Spat. Inf. 2009, 89, 1-2.

39. Hengl, T.; de Jesus, J.M.; MacMillan, R.A.; Batjes, N.H.; Heuvelink, G.B.M.; Ribeiro, E.; Samuel-Rosa, A.; Kempen, B.; Leenaars, J.G.B.; Walsh, M.G. SoilGrids1km—global soil information based on automated mapping. PLoS ONE 2014, 9, e105992. [CrossRef]

40. IBM. IBM SPSS Statistics for Windows, Version 21.0; IBM Corp: Armonk, NY, USA, 2012.

41. Guo, W.Y.; Lambertini, C.; Li, X.Z.; Meyerson, L.A.; Brix, H. Invasion of Old World P hragmites australis in the New World: Precipitation and temperature patterns combined with human influences redesign the invasive niche. Glob. Chang. Biol. 2013, 19, 3406-3422. [CrossRef] [PubMed]

42. Mainali, K.P.; Warren, D.L.; Dhileepan, K.; Mcconnachie, A.; Strathie, L.; Hassan, G.; Karki, D.; Shrestha, B.B.; Parmesan, C. Projecting future expansion of invasive species: 663 comparing and improving methodologies for species distribution modeling. Glob. Chang. 2015, 664, 4464-4480. [CrossRef]

43. Phillips, S.J.; Dudík, M.; Schapire, R.E. Maxent Software for Modeling Species Niches and Distributions (Version 3.4. 1). 2019. Available online: http//biodiversityinformatics.amnh.org/open_source/maxent (accessed on 1 November 2020).

44. Gallardo, B.; Aldridge, D.C. The 'dirty dozen': Socio-economic factors amplify the invasion potential of 12 high-risk aquatic invasive species in Great Britain and Ireland. J. Appl. Ecol. 2013, 50, 757-766. [CrossRef]

45. Jarnevich, C.S.; Young, N. Using the MAXENT program for species distribution modelling to assess invasion risk. In Pest Risk Modelling and Mapping for Invasive Alien Species; CAB International: Wallingford, UK, 2015; pp. 65-81. [CrossRef]

46. Norberg, A.; Abrego, N.; Blanchet, F.G.; Adler, F.R.; Anderson, B.J.; Anttila, J.; Araújo, M.B.; Dallas, T.; Dunson, D.; Elith, J. A comprehensive evaluation of predictive performance of 33 species distribution models at species and community levels. Ecol. Monogr. 2019, 89, e01370. [CrossRef]

47. Elith, J.; Phillips, S.J.; Hastie, T.; Dudík, M.; Chee, Y.E.; Yates, C.J. A statistical explanation of MaxEnt for ecologists. Divers. Distrib. 2011, 17, 43-57. [CrossRef]

48. Jiménez-Valverde, A.; Peterson, A.T.; Soberón, J.; Overton, J.M.; Aragón, P.; Lobo, J.M. Use of niche models in invasive species risk assessments. Biol. Invasions 2011, 13, 2785-2797. [CrossRef] 
49. Thapa, S.; Chitale, V.; Rijal, S.J.; Bisht, N.; Shrestha, B.B. Understanding the dynamics in distribution of invasive alien plant species under predicted climate change in Western Himalaya. PLoS ONE 2018, 13, e0195752. [CrossRef]

50. WWF. Terrestrial Ecoregions: Temperate Coniferous Forest. 2018. Available online: https://www.worldwildlife.org/biomes/ temperateconiferous-forest (accessed on 7 March 2018).

51. Phillips, S.J.; Anderson, R.P.; Schapire, R.E. Maximum entropy modeling of species geographic distributions. Ecol. Modell. 2006, 190, 231-259. [CrossRef]

52. Allouche, O.; Tsoar, A.; Kadmon, R. Assessing the accuracy of species distribution models: Prevalence, kappa and the true skill statistic (TSS). J. Appl. Ecol. 2006, 43, 1223-1232. [CrossRef]

53. Franklin, J. Mapping Species Distributions: Spatial Inference and Prediction; Cambridge University Press: Cambridge, UK, 2010; ISBN 1139485296.

54. Lawson, C.R.; Hodgson, J.A.; Wilson, R.J.; Richards, S.A. Prevalence, thresholds and the performance of presence-absence models. Methods Ecol. Evol. 2014, 5, 54-64. [CrossRef]

55. Riordan, E.C.; Montalvo, A.M.; Beyers, J.L. Using Species Distribution Models with Climate Change Scenarios to Aid Ecological Restoration Decisionmaking for Southern California Shrublands; Res. Rep. PSW-RP-270; U.S. Department of Agriculture, Forest Service, Pacific Southwest Research Station: Albany, CA, USA, 2018; 130p.

56. Phillips, S.J.; Anderson, R.P.; Schapired, R. Maxent Software for Species Distribution Modeling. ATET Labs-Research, Princeton University; Center for Biodiversity and Conservation, American Museum of Natural History: New York, NY, USA, 2011; Available online: http / / www.cs.princeton.edu/ \{\}schapire/maxent/ (accessed on 18 February 2011).

57. Gillham, J.H.; Hild, A.L.; Johnson, J.H.; Hunt, E.R.; Whitson, T.D. Weed Invasion Susceptibility Prediction (WISP) model for use with geographic information systems. Arid L. Res. Manag. 2004, 18, 1-12. [CrossRef]

58. Srinivasu, V.; Toky, O.P. Effect of alkalinities on seed germination and seedling growth of important arid trees. Indian J. For. 1996, $19,227-233$.

59. Theoharides, K.A.; Dukes, J.S. Plant invasion across space and time: Factors affecting nonindigenous species success during four stages of invasion. New Phytol. 2007, 176, 256-273. [CrossRef] [PubMed]

60. Geesing, D.; Al-Khawlani, A.; Abba, M.L. Management of introduced Prosopis species: Can economic exploitation control an invasive species? Unasylva 217 2004, 55, 289-299.

61. Anderson, L.W.J. California's reaction to Caulerpa taxifolia: A model for invasive species rapid response. Biol. Invasions 2005, 7, 1003-1016. [CrossRef]

62. Martin, Y.; Van Dyck, H.; Dendoncker, N.; Titeux, N. Testing instead of assuming the importance of land use change scenarios to model species distributions under climate change. Glob. Ecol. Biogeogr. 2013, 22, 1204-1216. [CrossRef]

63. Rohli, R.V.; Andrew Joyner, T.; Reynolds, S.J.; Shaw, C.; Vázquez, J.R. Globally extended Köppen-Geiger climate classification and temporal shifts in terrestrial climatic types. Phys. Geogr. 2015, 36, 142-157. [CrossRef]

64. Pasiecznik, N.M.; Harris, P.J.C.; Smith, S.J. Identifying Tropical Prosopis Species: A Field Guide; HDRA Publishing: Coventry, UK, 2004.

65. Yue, Y.; Li, M. Is the impact of climate change on desertification predictable? In Proceedings of the EGU General Assembly Conference Abstracts, Online, 4-8 May 2020; p. 6141.

66. Walter, K. Prosopis, an Alien among the Sacred Trees of South India. Ph.D. Dissertation, Department of Forest Sciences, University of Helsinki, Faculty of Agriculture and Forestry, Helsinki, Finland, 2011.

67. El-Keblawy, A.; Al-Rawai, A. Effects of seed maturation time and dry storage on light and temperature requirements during germination in invasive Prosopis juliflora. Flora-Morphol. Distrib. Funct. Ecol. Plants 2006, 201, 135-143. [CrossRef]

68. Shaltout, S. Ecological Study on the Alien Species in the Egyptian Flora. Master's Thesis, Faculty of Science, Tanta University, Tanta, Egypt, 2014.

69. El-Keblawy, A.; Al-Rawai, A. Effects of salinity, temperature and light on germination of invasive Prosopis juliflora (Sw.) DC. J. Arid Environ. 2005, 61, 555-565. [CrossRef]

70. Shaltout, K.H.; El-Hennawy, M.; Nafeaa, A.; Afefe, A.A.; Abo-Bakr, S.; Ghazaly, O.; Eid, E.M.; Fouda, M. National Progress Towards Targets of the Global Strategy for Plant Conservation. Egyptian Environmental Affairs Agency; Nature Conservation Section (NCS): Cairo, Egypt, 2009.

71. Zhou, Z.; Yu, M.; Ding, G.; Gao, G.; He, Y. Diversity and structural differences of bacterial microbial communities in rhizocompartments of desert leguminous plants. PLOS ONE. 2020, 15, e0241057. [CrossRef]

72. Abbas, A.M.; Mancilla-Leytón, J.M.; Castillo, J.M.; Mancilla-Leytón, J.M.; Castillo, J.M. Can camels disperse seeds of the invasive tree Prosopis juliflora? Weed Res. 2018, 58, 221-228. [CrossRef]

73. Abbas, A.M.; Mahfouz, L.; Ahmed, M.K.; Al-Kahtani, M.A.; Ruxton, G.D.; Lambert, A.M. Effects of seed passage by sheep on germination of the invasive Prosopis juliflora tree. Small Rumin. Res. 2020, 188, 106098. [CrossRef]

74. Catford, J.A. Hydrological impacts of biological invasions. In Impact of Biological Invasions on Ecosystem Services; Springer: Cham, Switzerland, 2017; pp. 63-80.

75. Choge, S.; Clement, N.; Gitonga, M.; Okuye, J. Status Report on Commercialization of Prosopis Tree Resources in Kenya; KEFRI: Nairobi, Kenya, 2012.

76. Shackleton, R.T.; Le Maitre, D.C.; van Wilgen, B.W.; Richardson, D.M. Identifying barriers to effective management of widespread invasive alien trees: Prosopis species (mesquite) in South Africa as a case study. Glob. Environ. Chang. 2016, 38, 183-194. [CrossRef] 
77. Wise, R.M.; Van Wilgen, B.W.; Le Maitre, D.C. Costs, benefits and management options for an invasive alien tree species: The case of mesquite in the Northern Cape, South Africa. J. Arid Environ. 2012, 84, 80-90. [CrossRef]

78. Haji, J.; Mohammed, A. Economic impact of Prosopis juliflora on agropastoral households of Dire Dawa Administration, Ethiopia. African J. Agric. Res. 2013, 8, 768-779.

79. Wakie, T.T.; Hoag, D.; Evangelista, P.H.; Luizza, M.; Laituri, M. Is control through utilization a cost effective Prosopis juliflora management strategy? J. Environ. Manag. 2016, 168, 74-86. [CrossRef] [PubMed]

80. Kaur, R.; Gonzales, W.L.; Llambi, L.D.; Soriano, P.J.; Callaway, R.M.; Rout, M.E.; Gallaher, T.J. Community impacts of Prosopis juliflora invasion: Biogeographic and congeneric comparisons. PLoS ONE 2012, 7, e44966. [CrossRef]

81. Burkart, A. A monograph of the genus Prosopis (Leguminosae subfam. Mimosoideae). J. Arnold Arbor. 1976, 57, 450-525.

82. Cramer, W.; Guiot, J.; Fader, M.; Garrabou, J.; Gattuso, J.P.; Iglesias, A.; Lange, M.A.; Lionello, P.; Llasat, M.C.; Paz, S.; et al. Climate change and interconnected risks to sustainable development in the Mediterranean. Nat. Clim. Chang. 2018, 8, 972-980. [CrossRef]

83. Forzieri, G.; Feyen, L.; Rojas, R.; Flörke, M.; Wimmer, F.; Bianchi, A. Ensemble projections of future streamflow droughts in Europe. Hydrol. Earth Syst. Sci. 2014, 18, 85-108. [CrossRef]

84. El-Keblawy, A. Greening Gulf landscapes: Economic opportunities, social trade-offs, and sustainability challenges. In Environmental Politics in the Middle East; Oxford University Press: Oxford, UK, 2018; pp. 99-120.

85. Al-Rawahy, S.H.; Al-Dhafri, K.S.; Al-Bahlany, S.S. Germination, Growth and Drought Resistance of Native and Alien Plant. Asian J. Plant Sci. 2003, 2, 1020-1023.

86. Warrag, M.O.A. Autotoxicity of mesquite (Prosopis juliflora) pericarps on seed germination and seedling growth. J. Arid Environ. 1994, 27, 79-84. [CrossRef]

87. Dzikiti, S.; Schachtschneider, K.; Naiken, V.; Gush, M.; Moses, G.; Le Maitre, D.C. Water relations and the effects of clearing invasive Prosopis trees on groundwater in an arid environment in the Northern Cape, South Africa. J. Arid Environ. 2013, 90, 103-113. [CrossRef]

88. Schachtschneider, K.; February, E.C. Impact of Prosopis invasion on a keystone tree species in the Kalahari Desert. Plant Ecol. 2013, 214, 597-605. [CrossRef]

89. Seddon, A.W.R.; Macias-Fauria, M.; Long, P.R.; Benz, D.; Willis, K.J. Sensitivity of global terrestrial ecosystems to climate variability. Nature 2016, 531, 229-232. [CrossRef] [PubMed] 